解 説

\title{
大腰筋・脊柱彎曲・二足歩行の生体力学的関係 一計算機シミュレーション研究—
}

\author{
長 谷 和 徳* 山 崎 信 寿**
}

\section{要旨}

全身で 46 の筋モデルと 14 節の剈体リンク系からなる3 次元神経筋骨格モデルを基本として大腰筋の有無と 脊柱彎曲の有無とを組み合わせた4種類の歩行モデルを構築し, 各モデルについて歩行運動の計算機シミュレー ションを行った。得られた運動パターンは各モデルごとで顕著な相違はなく,むしろ移動仕事率や筋負担などの 生体内負荷は大腰筋や脊柱彎曲がないモデルの方が少なかった. しかしながら, 歩行運動の途中で骨盤節に外力 を作用させるシミュレーション実験を行った結果, 脊柱彎曲と大腰筋がある通常の筋骨格モデルが最も安定した 持続歩行を実現できた. 大腰筋の機能は静的な姿勢支持や運動の効率性よりも動的な運動の安定性の向上に奇与 していると推察される.

1.はじめに

まず著者らが大腰筋の機能に関心を持った経緯を簡単に紹介 したい. 図 1 は身体運動の逆動力学的解析を行うために我々が 開発した 3 次元全身筋骨格モデル 1,2)である.このモデルでは

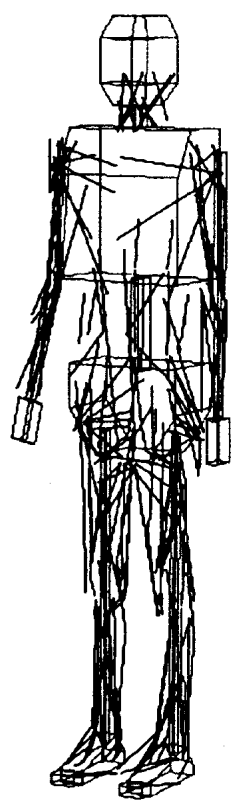

図 1 逆動力学的解析用の筋骨格モデル

\footnotetext{
2000 年 5 月 16 日受付

*生命工学工業技術研究所

干 305-8566 茨城県つくば市東 1-1

E-mail : hase@nibh.go.jp

$* *$ 慶應義熟大学·理工学部
}

キーワード：神経筋骨格モデル，最適化計算，移動仕事率，筋負 担, 歩行の安定性
全身の筋の解剖学的特長をできるだけ精密に表現するため, 全 身で156の筋をモデル化してある。このように多くの筋を考慮 したにもかかわらず，実はこの筋骨格モデルには大腰筋に相当 する筋が含まれていない. その理由は純粋に数値計算上の問題 からである.このモデルでは実際のヒトの身体運動における運 動変位や外力の計測データを入力条件として, 逆動力学問題を 解くことで関節モーメントを, 更には最適化計算を行うことで 筋張力を算出することができる.この際にもし大腰筋を無視し てしまえば, 左右の下肢と体幹とは筋骨格系の力学的構造の上 で独立に扱うことができるため, 筋張力を求める最適化計算を 左右の下肢, 体幹の筋群に分割して, それぞれ個別に行うこと が可能となる. 逆にもし大腰筋を考慮したならば, 左右の下肢 と体幹の筋はすべて一つの筋群として扱う必要が生じてしまう。 そのため最適化計算では両下肢, 体幹の全ての筋の筋張力を同 時に未知数として考えなければならず, 計算が非常に複雑化し てしまう。我々はこのような理由で上記筋骨格モデルを構築す る際には大腰筋を無視してしまったのである. 逆にそのことが 大腰筋の特異性を感じるひとつのきっかけになった。

このように大腰筋は下肢と体幹との間に力学的な相互関係 を生じさせる唯一の筋であり, 大腰筋が存在するために筋骨 格系の力学的構造は格段に複雑化する。つまり, 身体構造を 単純化・モデル化して力学解析を行うエンジニアリング的な 発想では大腰筋は「邪魔」な筋として考えられる。しかし, 実 際の生体の運動発生機序を考えた場合，果たして本当に邪魔 な筋なのか，仮にもし邪魔ならば，なぜ進化の過程において 退化することなく逆に大きな断面積を持つ筋として存在して いるのか，という疑問が生じる，大腰筋の機能の考察は我々 のようなエンジニアの立場で身体運動を捉えている者にとっ ても身体運動の分析・解积に新しい視点を要求する注目すべ き研究トピックだと考える，現状では我々はまだこの問題に 対する完全な解答を持ち合わせているとは言えないが, ひと つの試みを以下に紹介したい。 


\section{2.方 法}

\section{1 大腰筋の機能の仮説}

大腰筋の力学的な機能について我々は一つの仮説を考えてい る. その仮説とは「大腰筋の機能は姿勢保持のような静力学的 要因だけでは説明できず，二足歩行のような動的な身体運動と 関連して説明されるべきである。さらに大腰筋の機能は脊柱の 彎曲形状とも深く関与している.すなわち, 大腰筋と脊柱彎曲 の力学的機能の相乗効果が直立二足歩行に関する何らかの力学 特性の向上に寄与している」というものである. 大腰筋だけで なく, 春柱彎曲の生体力学的意義についても特に進化人類学分 野では盛んに議論されている ${ }^{3,4)}$. 脊柱に直接付着し，下肢運動 の影響を脊柱に伝播し得る大腰筋はこの脊柱彎曲形状の形成に 何らかの影響を与えており, 逆に脊柱の形状特性は大腰筋の機 能に何らかの影響を与えていると考えられる。 そして，これら の力学的特性は特に直立二足歩行という動的な運動への適応問 題として考えるべき，との仮説である.

\section{2 計算機シミュレーションによる仮説の検証}

このような仮説の検証のためには，大腰筋・脊柱彎曲・直立 二足歩行の相互関係を総合的に分析する必要がある. 最も直感 的な上記仮説の検証方法は「大腰筋があるヒトと大腰筋がない ヒト,さらには脊柱彎曲があるヒト, 脊柱彎曲がないヒトの組 み合わせを仮定し, それぞれのヒトの歩容を観察して各個体の 解剖学的特長と歩容との因果関係を分析する」というものであ ろう。このような実験条件を実際のヒトに求めるのならば，臨 床での症例や霊長類の二足歩行運動との比較など，ごく限られ た不均一で計測困難な条件に制約されることになり，その検証 は極めて困難となる，そこで, 我々は計算機シミュレーション 手法を用いた研究アプローチが, このような実際の生体を用い る実験的アプローチの限界を補完する手段として考え, 研究開 発を進めている. 計算機シミュレーションモデルにおいて脊柱 攀曲形状や大腰筋の解剖学的特長を表現することができ,かつ, それらの力学的特性を反映した二足歩行運動を自律的に生成す ることができれば，上記のような仮説を容易に検証することが できる. 本研究ではこのような計算機シミュレーション手法を 用いて大腰筋・脊柱彎曲・および二足歩行の生体力学的関係の 解明を試みる。

\section{3 シミュレーション実験}

シミュレーションに用いた二足歩行の神経筋骨格モデルの概 略を図 2 に示す．このモデルの詳細は文献5)を参照されたい. このモデルは3次元の筋骨格モデルと自律的な神経系のリズム 発生機構を表す神経モデルから成る.筋骨格モデルは全身で 14 節の剛体リンク系と 46 の筋モデルから構成される．体幹部は 骨盤節，腰椎下部節，腰椎上部節，胸部節の 4 つに分割してあ り，単純ではあるが脊柱の彎曲形状を表現できるようになって いる．各筋の走行状態は折れ線のようにモデル化されており， その幾何学的配置は関節角度に応じて変化する.腸骨筋と大腰 筋とで構成される腸腰筋群は腸骨筋, 下部大腰筋, 上部大腰筋 の3つの筋モデルによって表現されている. 神経モデルは体性
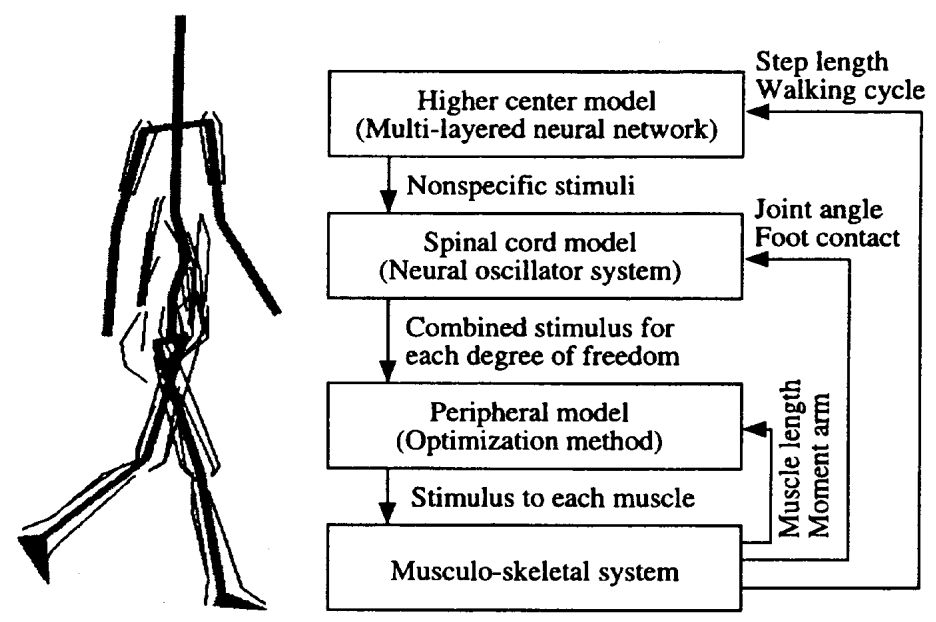

図 2 二足歩行シミュレーション用の神経筋骨格モデル

感覚フィードバックと上位中枢からの定常信号を入力条件とし て神経系の基本リズムを発生する春䯣レベルモデルと, 個々の 筋への筋刺激を生成する末梢レベルモデルからなる，春髄レベ ルモデルは数学的には神経系の central pattern generator $(\mathrm{CPG})$ を モデル化した神経振動子を構成素子とした相互結合型のニュー ラルネットワークにより表される．また，末梢レベルモデルで は筋疲労の最小化を目的関数とした最適化計算が行われる.

シミュレーション実験の条件として脊柱彎曲の有無と大腰筋 の有無の組み合わせで構成される4種類の筋骨格モデルを想定 した，すなわち，脊柱彎曲あり・大腰筋ありモデル，春柱彎曲

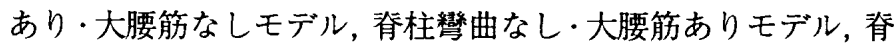
柱彎曲なし・大腰筋なしモデル，の 4 通りである. 図 3 にその 概要を示す，図では腰部を中心にモデル化した腸腰筋群のみを

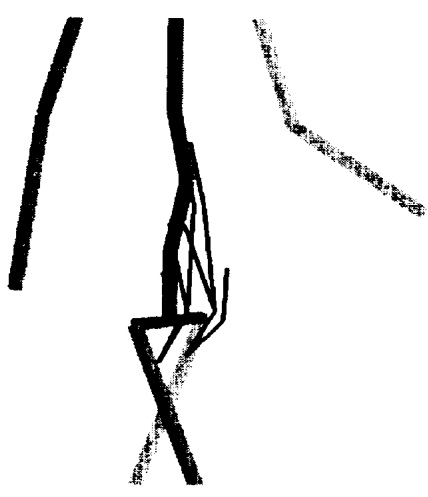

(a) 㤗柱警曲あり・大震觔ありモテル
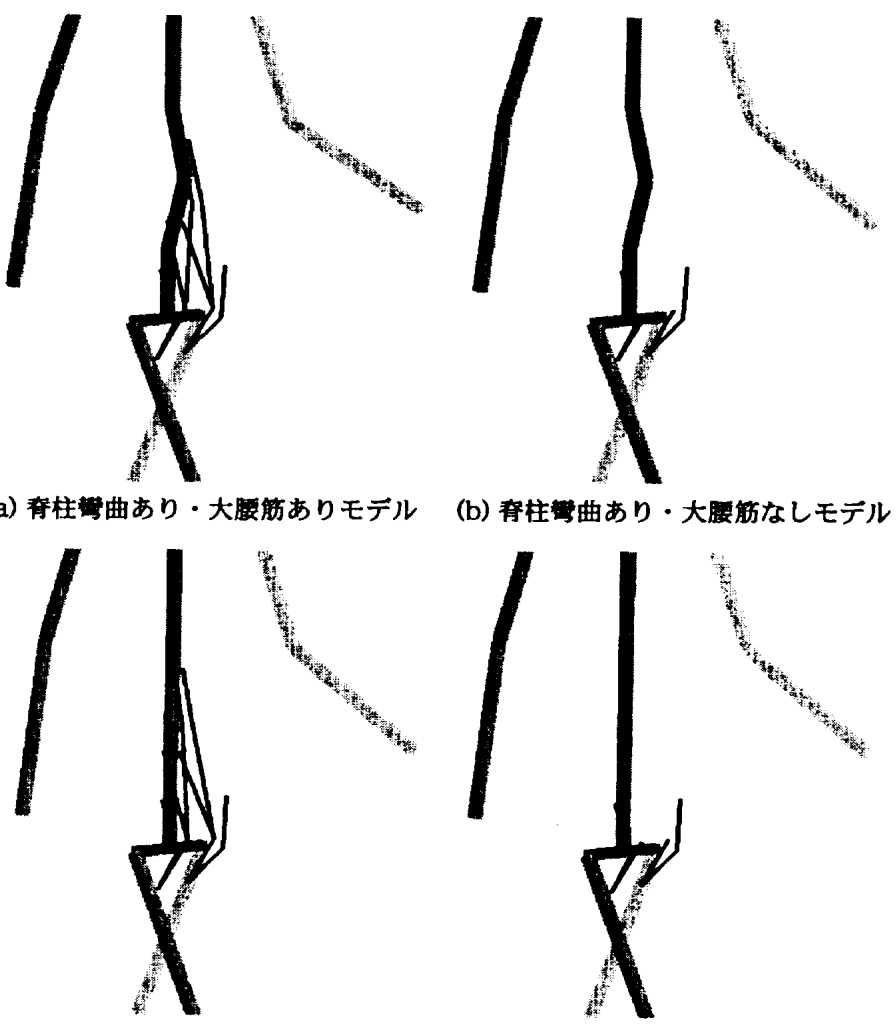

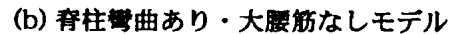

(c) 奉柱等曲なし・大腰筋ありモデル

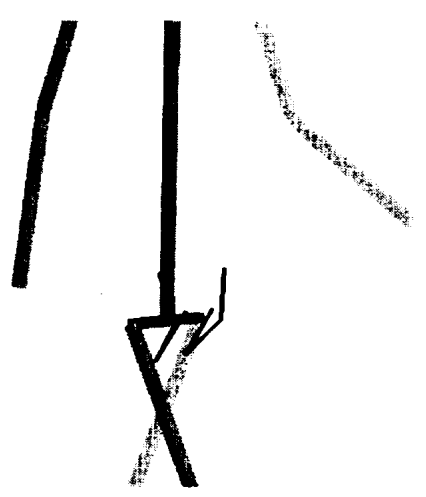

(d) 奉柱誉曲なし・大雯筋なしモデル 図 3 シミュレーション実験用の筋骨格モデル 
示している．脊柱彎曲あり・大腰筋ありモデルが通常の筋骨格 モデルに相当し，それ以外は仮想的な筋骨格構造となる．大腰 筋なしモデルでは実際には大腰筋を全て無くしてしまうのでは なく，大腰筋に相当する筋の起始点を脊柱(腰椎節)から骨盤節 へ移動させ, 基本的に腸骨筋と同等の機能を有するようにした。

それぞれの歩行モデルについてヒト歩行の運動決定規範と考 えられている水平移動のエネルギ効率を示す移動仕事率6)を評 価基準として,これを最小化するように各神経系のパラメー夕 の探索・最適化計算を行った，移動仕事率は身体でのエネルギ 消費量を体重と移動距離で除した值として定義される。このよ うな探索計算過程は生体における一種の運動学習過程の数学モ デルと考えることもできる.

この探索計算には歩行運動の生成と神経系パラメー夕の修正 とを数千回以上繰り返す必要があり, 莫大な計算コストとなる. そのため, 従来ではワークステーションなどの比較的高価な計 算機システムを必要としていた。しかしながら, 近年はパーソ ナルコンピュータ (PC)の高性能化, 低価格化に伴い, PC でも 充分に高度な科学技術計算が行えるようになってきた. 本研究 では Beowulf 型 7,8) と呼ばれる PC クラスタシステム(ナべ・イ ンターナショナル:TAKERU2000)を用いてシミュレーション計 算を行った. 本システムは 10 台のノードマシンと 1 台のホス トマシンから構成されるが, 各マシンは通常のPC とほほ同等 の構成である．また，ノードマシンを追加することで, 容易に 計算処理能力を向上させることができるスケーラビリティを有 していることも特徴である.シミュレーションでは 6 歩の歩行 運動の生成を 1 試行として, 5000 回の繰り返し計算を行った. さらにこの計算を大腰筋の有無などの上記の4つの条件につい て行った.これらの計算には本計算機システムを用いて合計約 30 時間を要した.

\section{3.シミュレーション結果}

3.1 歩容と生体内負荷の評価

図 4 に各モデルにおける歩行のシミュレーション結果を示 す.計算では 6 歩の連続歩行のシミュレーションを行ったが, 図にはそのうちの 1 周期分の歩行を 0.1 秒間隔で表示してある. また，図 5，6に歩速などの歩行の基本因子を筋骨格モデル条 件ごとに比較した結果を示す，移動仕事率の定義は 2.3 節で簡 単に示したが, この指標は小さい值の方が良いとされる.また 筋負担は筋張力の時間積分值を体重と移動距離で除した值であ り, 次元は異なるが移動仕事率と同様の形式(移動仕事率は土ネ ルギ消費を体重と移動距離で除した值)であり,值が小さいほど 筋への負担が小さいと評価できる. 図ではこの值を脊柱彎曲あ り・大腰筋ありモデル(通常の筋骨格モデル)の值で正規化して 表示してある。

これらの結果から各モデルごとの歩容, すなわち関節角度パ ターンや歩速，ストライド長などに顕著な相違は見られない. したがって, 大腰筋の有無などの筋骨格系の影響が歩容全体に 大きく影響を及はしているとは考えにくい. また, 移動仕事率 や筋負担の指標から判断すれば，むしろ脊柱彎曲なし・大腰筋 なしモデルの方が生体内負荷の小さい運動パターンを生成でき

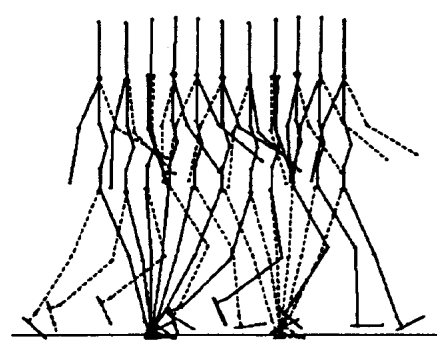

(a) 茟柱曲あり・大腰筋ありモテル

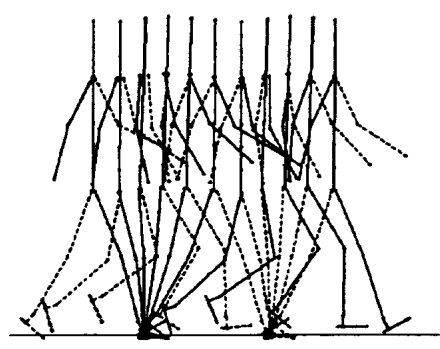

(c) 奇柱韭曲なし・大腰筋ありモテル

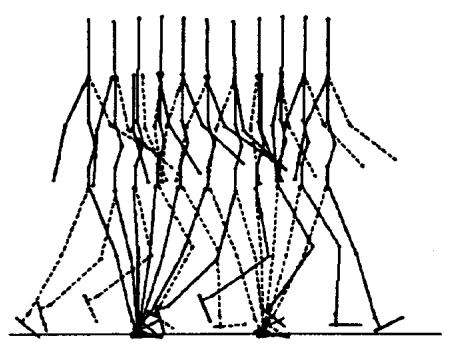

(b) 奇柱曲あり・大腰筋なしモテル

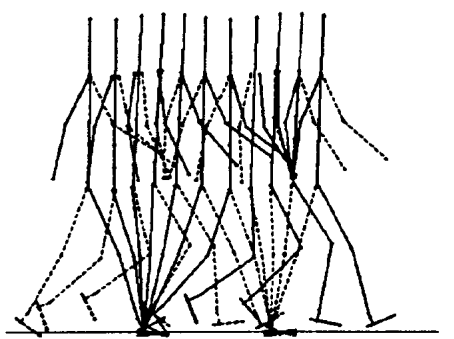

(d) 奔柱学曲なし・大委筋なしモテル
図 4 シミュレーション結果

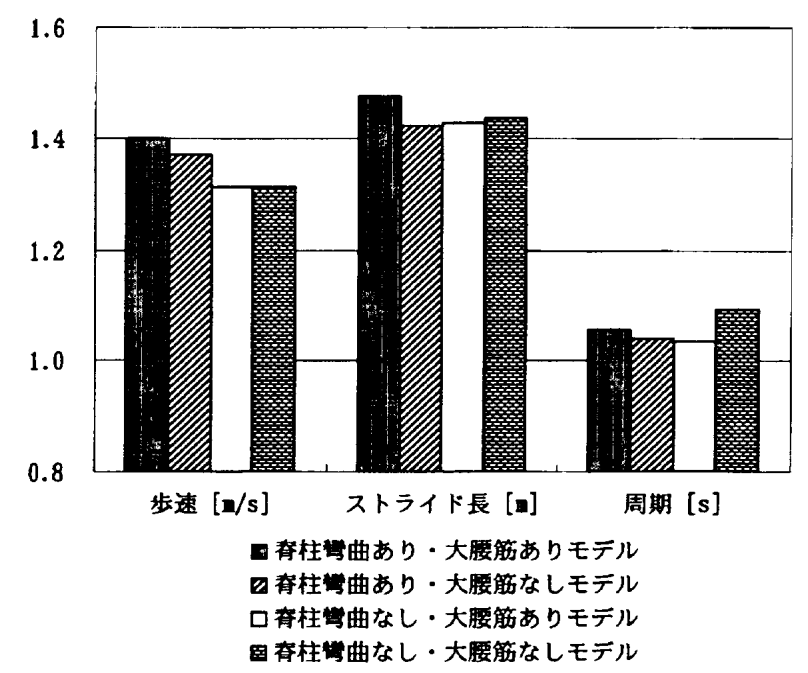

図 5 歩容の基本因子の比較

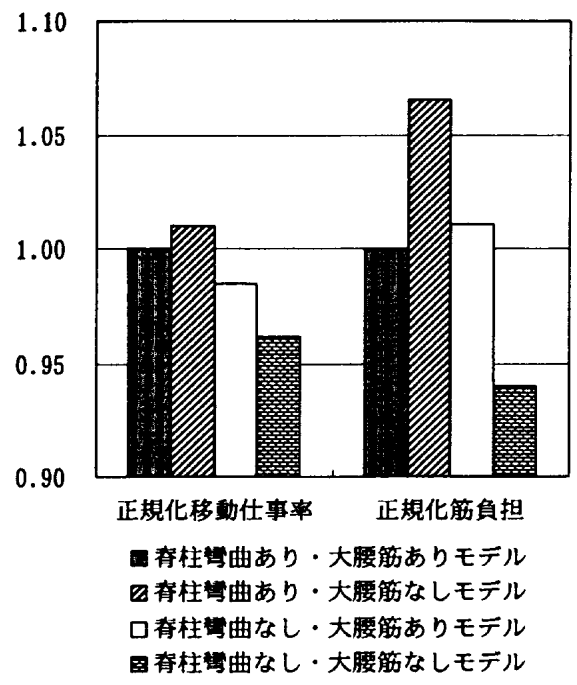

図 6 生体内負荷の比較 
ると言える．単純な構造力学的観点からみれば，もし体幹を直 立に支持するだけならば，脊柱は彎曲しておらず，むしろ直線 的な方が静的な鉛直方向の負荷に対して強勒である。また，緒 言で記したように大腰筋がある場合, 筋活動の拮抗関係はより 複雑になるため, 筋骨格系全体としてのエネルギ効率や筋負担 は大腰筋がない場合よりも増加傾向を示すことも説明できよう. すなわち, 大腰筋や春柱彎曲形状が歩行の運動パターンに与え る影響は必ずしも大きくなく，またエネルギ効率や筋負担など の生体内負荷の観点からみると，むしろマイナスに働く可能性 も示唆される.

\section{2 歩行の安定性の評価}

身体運動の評価尺度としては上記のようにエネルギ消費や力 学的負担などの運動の効率性がまず第一義的に考えられる.し かしながら，ヒトの運動規範はそれだけが全てではない. 歩行 運動に関して我々は特に運動の「安定性」あるいは「強勒性」に 注目している。この歩行運動の「安定性」「強䩗性」の生体力 学的定義は難しく, 確立された評価指標は必ずしも存在しない. 歩行運動を非線形振動理論の観点から見た場合, この安定性と はリミットサイクルに引き込むことができるアトラクタの幅に 相当するものであろう. 本研究では単純に歩行の安定性を「力 学的外乱, 例えば歩行途中に外力が作用した場合でも転倒せず に持続歩行を生成できる能力」として評価する。このような観 点から，それぞれの歩行モデルに対して歩行途中に外力を与え たときに転倒するか否かを観察し, 歩行の安定性の評価を行っ た. 外力の与え方として以下の 2 通りの方法を想定した. すな わち, (1) 右足の踵接地のタイミングから 0.2 秒の間, 進行方向 の逆向きに $170 \mathrm{~N}$ の力を骨盤節に作用させる, (2) 同様に右足の 踵接地の夕イミングから 0.2 秒の間, 右方向に $60 \mathrm{~N}$ の力を骨盤 節に作用させる. 図 7,8にこれらの外力を与えた場合のシミュ レーション結果を示す。このように脊柱彎曲あり・大腰筋あり モデルではこれらの大きさの外力に抗して持続的な歩行を生成 できたが，それ以外のモデルでは歩容が乱れてしまい，最終的 には転倒してしまった。すなわち, 脊柱彎曲あり・大腰筋あり という実際のヒトに対応したモデルが最も力学的外乱に対して 安定した歩行を生成できると言える，ただし，脊柱彎曲あり・ 大腰筋ありモデルの歩容の安定性とそれ以外のモデルの安定性 との差は必ずしも大きくはない.

\section{4. 考察とまとめ}

本研究では直立二足歩行と大腰筋との生体力学的関係を少柱 彎曲形状の問題とも絡めて計算機シミュレーション手法を用い て解明することを試みた。本研究はまだ考察不十分な部分もあ ク,シミュレーション結果の妥当性に関して検討すべき点がある ことは否めない. しかしながら, 我々は以下の点を主張したい. ひとつはバイオメカニクス研究における計算機シミュレー ション手法の有用性である.このような計算機シミュレーショ ン手法の妥当性・有効性の検証は必ずしも容易ではないが，実 験的アプローチでは実現できない仮想的な筋骨格条件などを容 易に実現できることから，実験的アプローチの限界を補完する

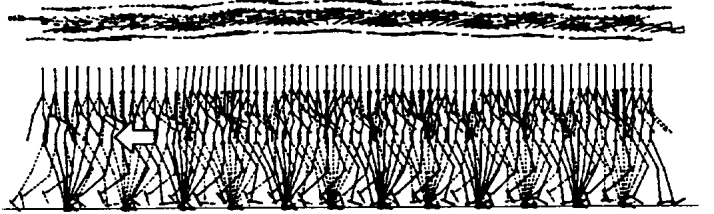

(a) 春柱誉曲あり・大霹筋ありモテル

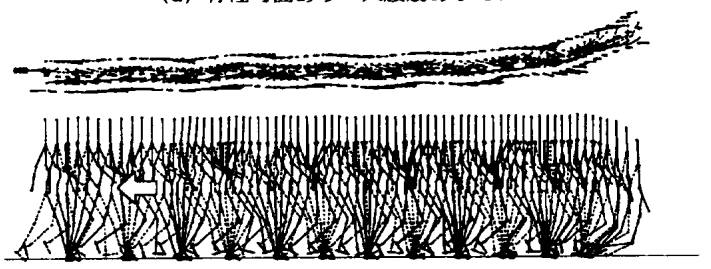

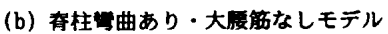

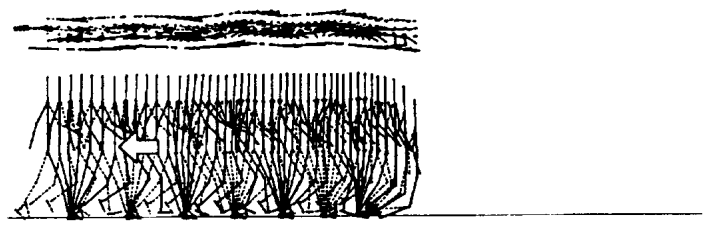

（c）春柱零曲なし・大要筋ありモテル

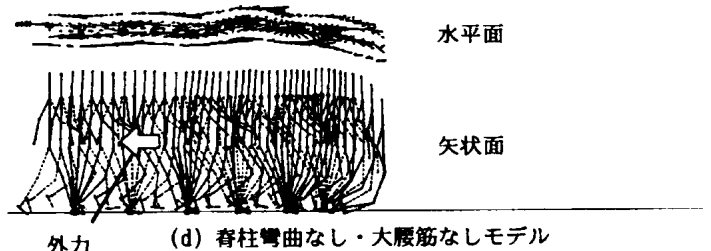

図7後乃方向に外力を作用させた場合のシミェレーション結果

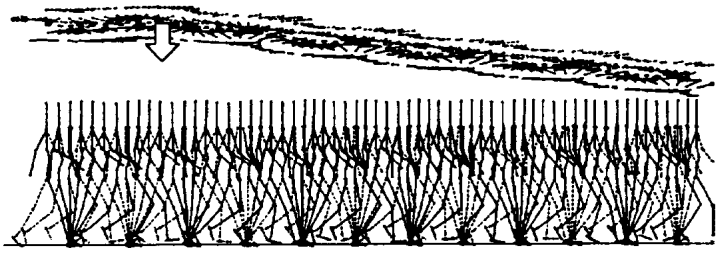

(a) 奇柱曲あり・大厔筋ありモテル

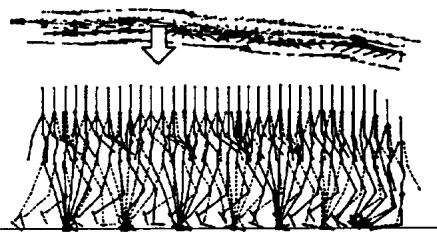

(b) 奇柱曲あり・大腰筋なしモテル

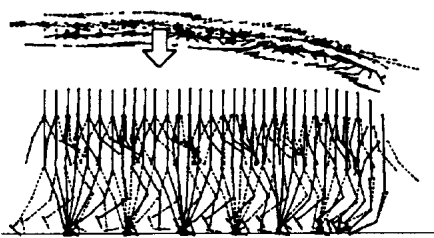

(c) 奉柱岁曲なし・大霓筋ありモデル

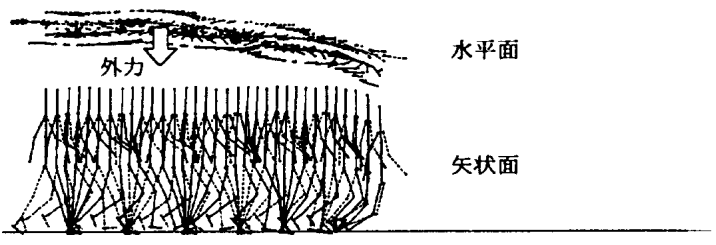

(d) 奉柱曲なし・大腰筋なしモテル

図 8 右方向に外力を作用させた場合のシミュレーション結果 
有効な研究手段だと考える. 本研究で議論の対象としている大 腰筋は特に筋電位の計測が困難な筋のひとつであり, その機能 の実験的検証は難しい. さらに大腰筋は下肢と体幹とを結ぶ特 異的な筋であるため, その運動機能特性を明らかにするために は下肢運動のみに注目するだけでも，また体幹運動だけに注目 するだけでも不十分であり，全身の運動を総合的に捉える必要 が考えられる. 本研究で用いた歩行の計算機シミュレーション 手法ではモデル化されている全ての筋や関節の力学特性を定量 的に評価することが可能であり，かつ大腰筋の有無のような仮 想的な筋骨格条件を設定することも容易である. したがって， 計算機シミュレーション手法は大腰筋の機能特性の解明にとっ て有効であり，その手法は他の筋や骨格構造に対する生体力学 的研究にも応用可能である.

もうひとつの主張点は身体運動の生体力学的評価尺度として, 運動の効率や負担軽減のような尺度とは異なる, 安定性の確保 のような運動の巧緻性に関する評価尺度の重要性である. 従来 のバイオメカニクス研究ではエネルギ消費量や筋張力の大きさ のように「如何に運動の負担が小さいか否か」という観点から の評価が中心であった. 歩行運動の評価基準としての移動仕事 率最小化のような指標 ${ }^{6}$ はそののつの例である。このような負 担軽滅に類する評価基準は第一義的に身体運動の運動規範であ るとの主張は今も正しいと考えているが, 生体には単なる効率 化，負担軽減だでは評価できない規範も存在し得るであろう。 大腰筋の機能はその最たるもので,この筋だけで筋骨格系の複 雑度を格段に增加させてしまっており，本シミュレーション結 果からも必ずしも運動効率の向上には寄与していないように考 えられる.しかしながら，本シミュレーションで示したように 歩行運動の安定性, 強勒性のような特性の向上には大いに寄与 している可能性が考えられる. 大腰筋は多関節筋の一種である が, 上肢や下肢の二関節筋には身体運動の制御特性の向上に密 接に結びついているとの研究結果が多〈報告されている ${ }^{9,10\rangle}$. 大腰筋にもそのような機能を有していると考えられ, 特に大腰 筋は股関節の屈伸運動, 脊柱支持に関与することから二足歩行 運動の巧緻性と密接に関与していると予想される. 脊柱彎曲に ついても単に静的な直立姿勢の保持としての機能を強調される ことが多いが,それよりも二足歩行のような動的な運動状態に おいてその意義を発揮するものと考える. 例えば衝撃の緩和の ような役割を担っているものと考えられよう. そして，その機 能は大腰筋と相互に作用することで，より強固なものになる。 骨盤や脊柱に作用する大腰筋の筋張力が股関節や腰椎関節の機 械インピーダンスを適度に高め, 力学的外乱に対する歩容の強 勒性を高めているものと予想される。

そもそも，このような運動の「安定性」や「強勒性」, あるい は「巧緻性」というのをどのように評価するか，また，これら をどのようなスカラーの評価指標によって定義するかが問題に なる.ささらにその理論的解明はより高度な問題であり, 単に運 動の効率だけでは説明できない身体運動のメカニズムを探って いく必要がある. 大腰筋と二足歩行の係わり合いの考察は我々 に生体の運動機序の解明をするための新たな研究視点を求めて いるように思える。

\section{参考文献}

1）長谷和徳, 山崎信寿：汎用 3 次元筋骨格モデルの開発, 日 本機械学会論文集 C 編, 61 (591), 4417-4422 (1995)

2) Hase, K., Yamazaki, N.: Development of three-dimensional whole body musculoskeletal model for various motion analyses, JSME International Journal, Series C, 40 (1), 25-32 (1997)

3）葉山杉夫：二足性獲得過程における猿まわしサルの脊柱 代償性彎曲, 成長, 33 (4), 161-178 (1986)

4) Preuschoft, H., Hayama, S., Gunther, M.: Curvature of the lumbar spine as a consequence of mechanical necessities in Japanese macaques trained for bipedalism, Folia Primatol, 50, 4258 (1998)

5）長谷和德, 西口純也, 山崎信寿 : 3 次元筋骨格系と階層的 神経系を有する 2 足歩行モデル, バイオメカニズム 15 , 東京大学出版会, 187-198, (2000)

6）山崎信寿, 長谷和徳：自由歩行における歩調・歩幅の生体 力学的決定基準, バイオメカニズム 11, 179-190, 東京大学 出版会, (1992)

7) http://www.beowulf.org/

8) http://www.beowulf-underground.org/

9) Kumamoto, M., Oshima, T., Yamamoto, T.: Control properties induced by the existence of antagonistic pairs of bi-articular muscles - Mechanical engineering model analyses, Human Movement Science, 13 (5), 611-634 (1994)

10）岸置武裕, 宮脇和人, 大日方五郎：FES 歩行のための下 肢乤長筋の運動学的機能解析, 日本機械学会論文集 C 編, 65 (636), 270-276 (1999)

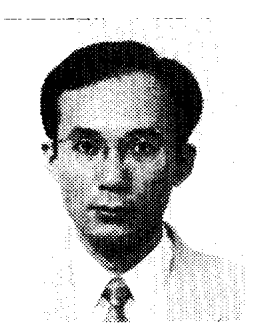

長谷和徳 (はせ かずのり) 1997年慶應義熟大学大学院博士課程修了, 同年工学博士. 同年通産省工業技術院生 命工学工業技術研究所入所. 99 年同所主 任研究官, 現在に至る. 計算機シミュレー ションによる身体運動の力学解析の研究 に従事. 機械学会, 計測自動制御学会, 人 類学会, ISB などの会員. (バイオメカニズム学会正会員)

\section{山崎信寿 (やまざき のぶとし)}

1976 年慶應義塾大学工学博士, 94 年教授. 身体の計測とモデ ル解析手法を開発し, 動物の運動特性の解明とその製品設計へ の応用を行っている. 機械学会, 人間工学会, 人類学会などの 会員. 86 年よりバイオメカニズム学会理事. 